\title{
THE LEGAL ENTITY OF BAITUL MAAL WAT TAMWIL (BMT) AS A MICRO FINANCIAL INSTITUTION IN INDONESIA
}

\author{
Moh. Syaifur Rijal \\ Mahasiswa Program Studi Magister Hukum Fakultas Hukum Universitas Airlangga \\ email: syaifurrijal123@gmail.com
}

\begin{abstract}
The purpose of this study is to analyze the legal status and accountability of Baitul Maal Wat Tamwil (BMT) as a financial institution in Indonesia, because so far BMT has two main functions, the first, Baitul Maal as a non-profit institution that distributes zakat, infaq and alms, and the second, Baitul Tamwil is an institution whose function is to collect and to distribute commercial funds. This research uses normative research using a statutory approach and a conceptual approach. The results of this study indicate that the legal status of BMTs so far can only be established with the status of a cooperative or limited liability company. It refers to the characteristics possessed by BMT itself. The form of BMT accountability follows the form of liability that exists in the form of a BMT legal entity, if the loss is caused by the management or organs, the management or organs are jointly and severally responsible, but otherwise if the management or organs can prove then the management or organs are not jointly responsible for the losses incurred by BMT.
\end{abstract}

\section{Keywords: BMT; legal entity; liability.}

\section{Introduction}

The presence of various types of financial institutions has a positive impact on the people of Indonesia, one of which is that people can freely choose the types of financial institutions and financing contained in these financial institutions, both conventional and sharia financial institutions. In order to reach middle- and lowerincome people, the government then formed a microfinance institution to provide easy access to finance. In general, they have difficulty in obtaining financing from banks.

Microfinance institutions in the Bank of Indonesia (BI) category are divided into two types, which are microfinance institutions in the form of banks and non-banking microfinance institutions. Microfinance institutions in the form of banks are such as Bank Rakyat Indonesia Village Unit (BRI village unit), Rural Bank (BPR), and so on. Meanwhile, non-banking microfinance institutions such as Savings and Loans Cooperatives (KSP), Rural Credit Funds, Baitul Maal Wat Tamwil (BMT), Non- 
Governmental Organizations (NGOs), Grameen Funding Pattern Arisan, ASA Financing Patterns, Community Self-Help Groups (KSM), Credit Union, and others (Neni Sri Imaniyati: 2010). One of the micro finance institutions that still exist today is Baitul maal Wat Tamwil or what is often known as BMT. The existence of BMT in Indonesia is none other than the existence of several advantages of BMT compared to other microfinance institutions, namely the existence of a concept (built in concept) with an orientation towards togetherness (Sumitro: 1996).

BMT as part of a microfinance institution in carrying out its business activities is based on sharia principles. One of the types of financing contained in BMT is the profit sharing system (Mudharabah, Musyarakah), the mark-up system (Murabahah, Bai'u Bithaman Ajil, Ba'i Assalam, Ba'i Istishna '), the rental system (Ijarah). , and benevolent loans (Qard Al-Hasan) and others (Widiyanto: 2016). The business activity system used by BMT is almost completely the same as the work pattern found in Islamic banking in general, that is being an intermediary institution that functions to collect and distribute funds either to members or to the public in general. BMT financing comes from this intermediation function. The funds that are saved by the community to BMT in the form of savings, distributed to people who are in need of financing to develop their business.

In the beginning, BMT was a non-profit organization that functioned to distribute zakat, infaq, and alms funds or only as a social amil institution (baitul maal) as happened during the time of the Prophet Muhammad (Dewi: 2017). Baitul Maal currently has a wider function, not only as a social institution that functions to distribute zakat, infaq and alms funds, but also manages the funds to be used as capital for the community so that they can carry out and develop their business activities, so as to improve conditions economy in the community (baitul tamwil). Until now, BMT has carried out two types of activities, baitul maal and baitul tamwil

The status of the BMT legal entity itself when viewed based on the forms of cooperation that exist in Indonesia, including (Achmad: 2012):

1. Associations that aim to obtain material benefits:

a. Civil unions (maatschaap), are regulated in the Civil Code. 
b. Firma (firma fellowship) is regulated in the Civil Code.

c. Limited Liability Companies, regulated in Law Number 40 of 2007 concerning Limited Liability Companies.

2. Associations that aim to achieve the welfare of its members or society:

a. Association, regulated in the Civil Code.

b. Cooperatives, regulated in Law Number 25 of 1992 concerning Cooperatives.

c. Foundations, regulated in Law Number 28 of 2004 concerning Foundations.

Based on this type of cooperation, BMT legal entities can be grouped into three groups: first BMT incorporated as a cooperative, second BMT incorporated as a foundation, and the third BMT that does not have a legal entity. Having a choice for BMT to determine which legal entity to use will certainly have different legal consequences according to the legal entity being used.

. The upholding of BMT commonly comes from the initiative of Muslim community such as Islamic boarding school or Islamic organizations. They usually have a commitment to conduct Islamic transaction free from usuary, uncertainty or gambling as well as to accommodate the spiritual right od muslim consumers to get financing and social facility based on Islamic law. According to Ro'fah Setyowati, spiritual rights should have legitimacy in Indonesian law (Setyowati, 2018). Herein, the entity of BMT must be clear to reach legal certainty. Therefore, research is needed on the legal entity of BMT as a microfinance institution and the form of liability for BMT as a legal entity in Indonesia.

\section{Research methods}

The research used is normative research, namely a know-how activity in legal science, not just know-how, as a know-how activity, legal research is carried out to solve legal issues at hand. Therefore it takes the ability to identify legal problems, carry out legal reasoning, analyze the problems faced and then provide solutions to these problems (Marzuki: 2016). 
The research approach used in this study is a statute approach and a conceptual approach. The statutory approach is a legal research that uses statutory regulations as an approach. The statutory approach is used by analyzing all laws and regulations relating to the legal issues discussed. For academic activities, researchers must look for the ratio legis and basis for the issuance of the law, so that later an appropriate rule can be found in solving a problem (Marzuki: 2016).

The second approach used is the conceptual approach. The conceptual approach is used by examining theories and doctrines that are used as references so that they are able to understand a view and doctrines in solving legal issues that are being discussed. The conceptual approach connects an existing concept with the issue of research law that is currently being discussed regarding legal entity issues of baitul maal wat tamwil (BMT) and the liability of BMT as a legal entity in Indonesia.

\section{Analysis of Legal Objects}

Analysis of legal materials is carried out by linking existing legal materials, then a review is carried out to obtain a systematic explanation. Furthermore, the materials needed in the discussion are separated in order to make it easier and get an understanding of the discussion that will produce a conclusion and can be used to solve and answer problems in this study. The legal materials that are processed from this research are then analyzed by interpreting and compiling the statements contained in general documents and laws and then concluding to be specific to answer a problem that is being discussed.

\section{Result and Discussion}

The Legal Status of Baitul Maal Wat Tamwil (BMT) as a Microfinance Institution in Indonesia

Baitul Maal Wat Tamwil (BMT) is a sharia microfinance institution which in carrying out its business activities uses the principle of profit sharing, develops businesses in micro-businesses and defends the interests of the middle to lower class society. BMT was founded on the pioneers of local community leaders with reference to the same economic system, which is safety, peace and prosperity (Juhaya S. Praja: 
2012). BMT itself consists of two words which have their own meanings, Baitul Maal and Baitul Tamwil. The word Baitul Maal comes from Arabic which has the meaning of "treasure house" or "state treasury," which is an institution established in the Islamic government to take care of all state finances. Baitul Maal is also a state financial institution that has the function of receiving, storing, and distributing money or state treasury in accordance with Islamic law (Mardani: 2015). The meaning of Baitul Maal at present, especially in Indonesia is experiencing a narrowing of meaning, baitul maal does not just carry out the broad functions that were previously carried out by the government or state during the caliphate (Cokrohadikusumo: 2016). Baitul Maal is more defined as a social institution that functions to channel non-profit funds such as zakat, infaq and alms by implementing not only the government, but the private sector as well.

Meanwhile, the word Baitul Tamwil consists of the word bait which means "house" and tamwil which means "development of wealth". Baitul Tamwil is an institution that runs productive efforts to improve the quality of the activities of middle and low-income entrepreneurs by encouraging saving activities and supporting economic financing (Neni Sri Imaniyati: 2010). These efforts are an inseparable part of BMT as an institution to support the economic activities of the small community based on Islamic law. As a business institution, (Baitul Tamwil) BMT further develops and emphasizes its business in the financial sector in the form of savings and loans. In simple terms, BMT can be defined as a microfinance institution whose business activities adhere to sharia principles and have a function to empower the economy of the people, as well as having a social function by also participating as an institution that manages zakat, infaq and alms funds, so that BMT institutions have an important role in empower the economy (Praja: 2016)

The development of BMT in Indonesia is based on data from BMT Ventura Capital, which acts as a BMT association in Indonesia, in 2015 there were approximately 4,500 BMTs who were providing services to 3.7 million people. The total assets of BMT in 2015 are estimated to reach around Rp. 16 trillion, these services are managed by approximately 20 thousand people. Meanwhile, referring to data from the Ministry of Cooperatives and Small and Medium Enterprises, it shows 
that the total number of cooperative business units in Indonesia is approximately 150,223 business units spread throughout Indonesia.

As an institution that is established and operates in Indonesia, BMT must have a legal status (legal entity) in carrying out its duties and functions, so that its existence can be guaranteed and protected by applicable provisions. The following is the legal status (legal entity) in the Blac'k Law Dictionary "A body, other than a natural person, that can funtion legally, sue or be sued, and make decisions through agents." (Campbell: 1979)

Legal status is required by every institution / legal entity including BMT operating in Indonesia, so that the existence of BMTs can be guaranteed and protected by applicable legal provisions. Prior to the enactment of Law Number 1 of 2013 concerning Microfinance Institutions (Law No. 1/2013 concerning MFIs), BMTs were often faced with important problems related to BMT institutions, especially related to legal entities that were in accordance with BMTs themselves. Before the formation of Law No. 1/2013 concerning MFIs as the legal protection for BMT in Indonesia, the form of BMT legal entities can be grouped into three (3) groups: (Imaniyati : 2010).

1. Having a cooperative legal entity (Kopontren, KSP, KSU, KBMT, KSBMT);

2. foundation legal entity (although the use of a foundation's legal status for BMTs is not in accordance with the BMT guidebook issued by PINBUK)

3. Does not have a legal entity.

For now, the foundation legal entity is no longer relevant to the operational activities of BMT. Foundation legal entities are only in accordance with one of the functions of BMT engaged in the social sector, that is baitul maal. If the foundation wants to establish BMT, then BMT is only a business sector of the foundation itself, by participating in a maximum of $25 \%$ (twenty five percent) of the foundation's assets as stated in Article 7 paragraph (2) of Law Number 282004 concerning the Foundation.

After the formation of Law No. 1/2013 concerning MFI, especially in the transitional provisions of Article 39 of Law No. 1/2013 concerning MFIs, it is stated 
that "when this law came into effect, Village Banks, Village Lumbung, Market Banks, Employee Banks, Village Credit Agencies ( BKD), District Credit Agency (BKK), Small People Business Credit (KURK), District Credit Institution (LPK), Village Production Work Bank (BKPD), Rural Credit Business Entity (BUKP), Baitul Maal Wat Tamwil (BMT), Baitul Tamwil Muhammadiyah (BTM), and / or other equivalent institutions can still operate for up to a year from the time this law comes into force.

The form of a legal entity for BMTs in Law No. 1/2013 concerning MFI Article 5 paragraph (1) states that microfinance institutions must choose the form of a legal entity between a cooperative legal entity or a Limited Liability Company legal entity. So that when BMT chooses to be a cooperative, BMT must comply with laws and regulations relating to cooperatives such as Law Number 25 of 1992 concerning Cooperatives and Decree of the State Minister for Cooperatives and Small and Medium Enterprises of the Republic of Indonesia 17 / Per / M.KUKM / IX / 2015 concerning Supervision of Cooperatives. Likewise, if BMT chooses to be a Limited Liability Company, BMT must comply with Law Number 40 of 2007 concerning Limited Liability Companies.

In terms of function, BMT is a social institution that distributes social funds in the form of zakat, donations, and alms funds. Referring to Law Number 23 of 2011 concerning Zakat Management as referred to Article 16 paragraph (1), it is stated that "in carrying out their duties and functions BAZNAS, Provincial BAZNAS, District / City BAZNAS can form Zakat Distribution Units (UPZ) in government agencies, stateowned enterprises. state, private companies, and representatives of the Republic of Indonesia abroad, and can form UPZ at the level of sub-districts, sub-districts or other names, and other places. " Based on these provisions, BMT through its baitul maal can take position and take part as the Zakat Collection Unit (UPZ) of the National Amil Zakat Agency (BAZNAS) which participates in implementing zakat management and helps BAZNAS in general.

\section{Forms of Liability for Baitul Maal Wat Tamwil (BMT) as a Legal Entity in Indonesia}


According to the Big Indonesian Dictionary (KBBI), accountability implies the condition of being obliged to bear everything, if there is something, it can be sued, blamed, and so on (Poerwadaminta: 1976). In the legal dictionary, there are two terms which refer to accountability, liability and responsibility. According to Peter Mahmud Marzuki, responsibility is defined as liability. The term liability is within the scope of private law, where the definition of liability in this case is based on the position of a person or legal entity that is required to pay compensation after a legal event or legal action. For example, a person or legal entity is required to pay compensation to other people due to illegal actions so that the person or legal entity is harmed (Marzuki: 2016).

Liability is a broad legal term. In it refers to the most comprehensive meaning, covering almost every definite character of risk or responsibility, which depends or is possible. Liability is also a condition of being subject to an actual or potential obligation. Conditions for being responsible for actual or possible things such as losses, threats, crimes, costs or expenses. Conditions that create the task of implementing laws immediately or in the future (Campbell: 1976).

Liability in this case relates to BMT as a sharia microfinance institution, which in practice in accordance with Law No. 1/2013 concerning MFI, BMT can be incorporated as Limited Liability Companies or legal entities of cooperatives. With the option for BMT to be incorporated as Limited Liability Companies or cooperatives, of course there are differences regarding the responsibility for all losses suffered by BMT consumers. This is due to the consequences of choosing a legal entity for BMT, if BMT is legally incorporated as Limited Liability Companies, they must comply with Law No. 40/2007 on PT, on the other hand if BMT chooses to be a cooperative, then BMT must comply with Law No. 28/1992 on Cooperatives.

Based on the provisions in Article 5 paragraph (1) of Law No. 1/2013 concerning MFIs, BMT can be a cooperative. As previously explained, the legal protection for cooperatives is based on Law Number 28 of 1992 concerning Cooperatives. Article 21 of Law Number 28 Year 1992 concerning Cooperatives states that cooperatives have a cooperative organization consisting of meetings of members, administrators and supervisors. In the case that the cooperative is dissolved and 
bears losses, the members only bear the losses limited to the principal savings, mandatory savings, and the investment capital they have (Imaniyati: 2010). If the cooperative experiences a loss / debt or bankruptcy and the assets of the BMT are insufficient to cover these losses or to carry out obligations to third parties, the BMT management is jointly and severally liable. However, if the management can prove that the losses incurred by BMT are not due to the management's fault, the management is not jointly responsible for the losses.

Besides being able to take the form of a cooperative, BMT can also be in the form of a Limited Liability Company as stated in Article 5 paragraph (1) of Law No. 1/2013 concerning MFIs. BMT as a Limited Liability Company is a legal entity that is operated by the organs of a limited liability company. Limited Liability Company organs according to Law Number 40 of 2007 concerning Limited Liability Companies (Law No 40/2007 concerning Limited Liability Companies) are the people who run, manage and manage the company. If the BMT experiences a loss or bankruptcy, the loss or debt is only charged and borne on BMT's assets. So that if the assets of BMT are not sufficient to pay for losses or debts, then it does not involve the personal assets of investors or shareholders. Provisions like this occur only if BMT as a Limited Liability Company has been approved (Prasetya: 2011). On the other hand, if BMT as a Limited Liability Company has not received approval from the Ministry of Law and Human Rights, BMT can still carry out its business activities in accordance with the objectives of the BMT. Therefore, founders or shareholders can be held accountable if BMT as a Limited Liability Company has not received approval from KEMENKUMHAM (Legal and Human Right Ministry).

Shareholders will not be held accountable only if BMT as a Limited Liability Company has been legalized as a legal entity. If BMT has the status as a Limited Liability Company, then the party responsible is the Board of Directors and all founders and members of the Board of Commissioners as stated in Article 14 of Law No. 40/2007 on Limited Liability Companies states "Legal actions on behalf of a company that have not yet obtained legal entity status, are only may be done by all members of the board of directors together with all founders and all members of the 
board of commissioners of the company and all of them are jointly and severally responsible for these legal acts."

\section{Conclusion}

a. The legal status of BMT before the issuance of Law No. 1/2013 concerning MFIs is in the form of cooperatives, foundations, or non-governmental organizations (KSM). After Law No. 1/2013 on MFI was issued as a legal protection for BMT in Indonesia, BMT was only allowed to be in the form of a cooperative or limited liability company as stated in Article 5 of Law No. 1/2013 on MFI.

b. b. In choosing the form of cooperative legal status, BMT must comply with Law No. 28/1992 on Cooperatives. Likewise, if a BMT chooses to be incorporated as a Limited Liability Company, then BMT must comply with Law No. 40/2007 on Limited Liability Companies. The consequence is that if BMT experiences a loss / debt or bankruptcy, the form of liability for BMT organs or management will follow the provisions in Law No. 28/1992 on Cooperatives or Law No. 40/2007 on limited liability companies.

\section{REFERENCES}

Ahmad, B. (2015). Ekistensi dan implementasi hukum islam di Indonesia, Pustaka Pelajar.

Black, H.C. (1979). Black's Law Dictionary, Fifth Edition ST.Paul Minn, West Oublishing Co.USA

Cokrohadisumarto, W. b. M \& Ismail, A. G \& Wibowo, K A. (2016). BMT Praktik dan Kasus. Raja Grafindo Persada.

Dewi, N (2017). Regulasi Keberadaan Baitul Maal Wat Tamwiil (BMT) Dalam Sistem Perekonomian Di Indonesia, Jurnal Serambi Hukum, 11 (01), https://www.neliti.com/id/publications/163544/regulasi-keberadaan-

baitul-maal-wat-tamwil-bmt-dalam-sistem-perekonomian-di-indo

Imaniyati, N.S. (2010). Aspek-aspek hukum BMT. Citra Aditya Bakti.

Mardani. (2015). Aspek hukum lembaga keuangan syariah di Indonesia. Prenadamedia Group. 
Marzuki, P.M (2016). Penelitian Hukum Edisi Revisi. Prenadamedia Group.

Masyitoh, N.D. (2014). Analisis normatif undang-undang nomor 1 tahun 2013 tentang lembaga keuangan mikro (LKM) atas status badan hukum baitul maal wa tamwil (BMT), Jurnal Economica, 5 $5 \quad(2)$, https://journal.walisongo.ac.id/index.php/economica/article/view/768, DOI: $10.21580 /$ economica.2014.5.2.768

Praja, J.S. (2012). Lembaga Keuangan Syariah Suatu Kajian Teoritis Praktis, Pustaka Setia.

Poerwadaminta, W.J.S. (1975) Kamus Besar Bahasa Indonesia, Balai Pustaka Prasetya, R. (2011. Teori dan praktek perseroan terbatas, Sinar Grafika.

Setyowati, R. \& Purbasari, I. \& Fauzan, E.M. (2018). Consumers Spiritual Rights in the Islamic Banking Dispute Out of Court Settlement in Indonesia. Journal of Social Studies Education Research. 9 (4), p. 343

Warkum S. (1996). Asas-Asas perbankan islam dan lembaga-lembaga terkait (BMUI \& takaful) di Indonesia, Raja Grafindo. 